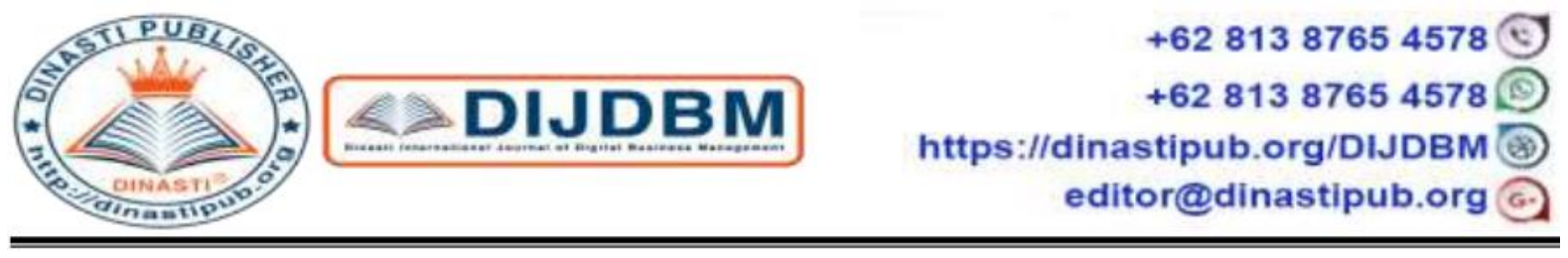

\title{
THE PRICE MECHANISM FUNCTION OF CURLY RED CHILLY IN THE CENTER OF PRODUCTION AND WHOLESALER
}

(The Case of Curly Red Chili Marketing at the Cikajang Garut Production Center and Kramat Jati) Wholesaler Market

\section{Dety Sukmawati $^{1)}$ Ning Srimenganti ${ }^{2)}$ Ida Marina $^{3)}$}

1,2,3) Agribisnis Universitas Winaya Mukti, Bandung, Indonesia

\begin{tabular}{|c|c|}
\hline $\begin{array}{c}\text { ARTICLE INFORMATION } \\
\text { Received: } 17^{\text {th }} \text { March } 2020 \\
\text { Revised: } 20^{\text {th }} \text { April } 2020 \\
\text { Issued: } 30^{\text {th }} \text { April } 2020 \\
\text { Corresponding author: } \\
\text { Dety Sukmawati } \\
\text { E-mail: } \\
\text { detysukmawati@ymail.com }\end{array}$ & $\begin{array}{l}\text { Abstract: The problem of red chili related to price } \\
\text { fluctuations has always been a concern for } \\
\text { farmers. Therefore, an increase in the production of } \\
\text { agricultural commodities including chili horticultural } \\
\text { commodities needs to be accompanied by improvements to } \\
\text { the marketing system. These research was quantitative } \\
\text { research, data collection was done by means of a survey of } \\
\text { time series . The data used are time series data and } \\
\text { supporting data which come from: Information center of } \\
\text { price at production center, and price information at West } \\
\text { Java Food Crop Agriculture Agency. From the amount of } \\
\text { data (included observation) which amounted to } 72 \text { data. The } \\
\text { technic analyzed used multivariate., the rational expectation } \\
\text { hypothesis of the supply function was analyzed by the } \\
\text { EVIEWS 8. the results of price analysis in Cikajang have a } \\
\text { dominant influence on prices in the PIKJ and vice versa, the } \\
\text { results of the analysis show that an increase in price of } 1 \\
\text { rupiah in Cikajang will increase the price in PIKJ 0.7679 } \\
\text { rupiah, or an increase in price of } 76.79 \% \text { meaning an } \\
\text { increase in prices in production centers will raised the price } \\
\text { of } 76.79 \% \text { in the PIKJ. PIKJ will quickly respond to price } \\
\text { increases in production centers even though the distance } \\
\text { from production centers to PIKJ was very far, the flow of } \\
\text { price information that occurs was actually one-way from } \\
\text { PIKJ to production centers. The response to the high price } \\
\text { increase was seen that the PIKJ was a price determinant and } \\
\text { when viewed from the marketing actors involved in it turns } \\
\text { out there were farmers in the production center which were } \\
\text { dealers or traders in the PIKJ. } \\
\text { Keywords: The Price Mechanism Function, Price } \\
\text { Fluctuations, Wholesaler. }\end{array}$ \\
\hline
\end{tabular}

\section{INTRODUCTION}

Marketing of chilli commodities provides an important contribution in improving the performance of chilli farming as a whole considering the unique nature of horticultural commodities in general such as perishable, perishable, voluminous, production is seasonal 
while consumption occurs throughout the year. These unique characteristics require a special treatment in the form of careful transportation, standard and good packaging, storage with a certain temperature, and various other preservation methods so that the commodity can last a long time. Meanwhile, on the other hand consumers want commodities to be available close to where they are, can be obtained all the time and can be consumed in fresh form. These two different desires will be fulfilled by having a good marketing system. The marketing channel involves various marketing institutions connecting farmers in production centers and consumption centers to provide value for products in a marketing system (Agustian \& Anugrah, 2009).

The problem of red chili related to price fluctuations has always been a concern for farmers. The very intensive increase in chili production at certain times often causes a drop in the price of chili on the market. This is because demand tends to remain in the short term while production is abundant (Eni Istiyanti, 2010).

Empirically in the field it is often found that producer farmers seem to still face price fluctuations, especially at harvest time, and it is the traders who have more access to be able to obtain higher prices. Therefore, an increase in the production of agricultural commodities including chili horticultural commodities needs to be accompanied by improvements in the marketing system, so that farmers as producers of these commodities are expected to obtain an adequate share of prices for increasing their farming (Agustian \& Anugrah, 2009). This study aims to determine the price mechanism that occurs in production centers and wholesale markets using the rational expectations model.

\section{LITERATURE REVIEW}

The main problem in the development of chili agribusiness is not yet realized the variety, quality, continuity of supply, and quantity in accordance with market demand, especially for the purposes of modern markets (supermarkets / hypermarkets), processing industries, institutional consumers (hotels, restaurants, hospitals), and export market. One of the problems is caused by the lack of coordination between agribusiness actors. This causes the institutional structure of the chili commodity agribusiness to be fragile and the linkage of supply chain management to be weak so that the competitiveness of chilli commodities becomes weak. The weak competitiveness of chilli commodities is a challenge in the implementation of agricultural development in the future, so there is a need for a strategy to increase the competitiveness of chilli commodities in order to compete in the market (Tsurayya \& Kartika, 2004).

In general, to distribute products to consumers, producers need marketing intermediaries, marketing can also be interpreted as the difference between the price paid by consumers and the price received by producers. This margin will be received by marketing institutions involved in the marketing process. The longer the marketing channel, the greater the marketing margin, because more and more marketing institutions are involved. The greater the marketing margin, the smaller the share of prices received by producer farmers compared to the prices paid by consumers, which means inefficient marketing channels (Eni Istiyanti, 2010).

Marketing becomes important as a process that must be passed by farmers as producers to distribute their products to consumers. Many marketing institutions involved in marketing activities and agricultural commodities usually have a long marketing chain, so the marketing process involves many marketing actors. This can cause an inefficient marketing system (Rasidin, Yusriadi, \& Rahman, 2018). 
One of the most important aspects of trade is the price which is an incentive received by traders (including farmers) in carrying out their economic activities. Various factors greatly affect prices, among others, from the supply side, the demand side, conditions and the structure of the trading system that occurs. One aspect that needs to be examined from the trading process is the price formation mechanism that occurs in commodity trading. By knowing the process of price formation, it can be identified the position of the relationship between the actors of the trade system which is essentially one of the dominant factors that determine the price level that occurs (Supriadi \& Sejati, 2018).

\section{RESEARCH METHODS}

These research was quantitative research, data collection was done by means of a survey of time series. The data used are time series data and supporting data which come from: Information center of price at production center, and price information at West Java Food Crop Agriculture Agency. From the amount of data (included observation) which amounted to 72 data. The technic analyzed used multivariate. The supply fuction was :

$$
\begin{array}{lll}
\mathrm{P}_{\text {ckj }}=\mathrm{h}_{0}+\mathrm{h}_{1} \mathrm{Pf}+\mathrm{h}_{2} \mathrm{P}_{\text {pigb }}+\mathrm{h}_{3} \text { Ppic } & \\
\mathrm{P}_{\text {ckj }} & =\text { Curly red chilly prices at } & \text { Kramat jati } \\
\mathrm{Pf} & =\text { Curly red chilly prices at } & \text { centra production } \\
\mathrm{P}_{\text {pigb }} & =\text { Curly red chilly prices at } & \text { Gede Bage } \\
\mathrm{Ppic} & =\text { Curly red chilly prices at } & \text { Caringin }
\end{array}
$$

The rational expectation hypothesis of the supply function was analyzed by the EVIEWS 8 program.

\section{FINDINGS AND DISCUSSION}

The price mechanism in this case consists of variable cikajang prices, PIG prices, PIKJ prices, and PIC prices, these 4 places want to see prices where the most dominant in the formation of curly red chili prices, although it has been analyzed by price transmission and market integration, this will show a dominant price mechanism among these places or markets. The equation below will see how the price mechanism is, if prices in the PIKJ are the dependent variable:

$$
\begin{gathered}
\text { H_KRMT_JATI }=1736.89915997+0.175654540823 * \text { H_GD_BAGE }+ \\
0.767985535458 * \text { H_CIKAJANG }+0.205684227344 * \text { HCARINGIN }
\end{gathered}
$$

H_KRMT_JATI : $P_{\text {ck }}=$ Curly red chilly prices at Kramat jati H_GD_BAGE : Ppigb= Curly red chilly prices at Gede Bage H_CIKAJANG: $\mathrm{Pf}=$ Curly red chilly prices at centra production HCARINGIN : Ppic= Curly red chilly prices at Caringin.

It can be seen that the results of the price analysis in Cikajang have a dominant influence on prices in the PIKJ and vice versa, the results of the analysis show that a price increase of 1 rupiah in Cikajang will increase the price in the PIKJ to 0.7679 rupiah, or an increase in price of $76.79 \%$, meaning an increase in prices in the center production will raise the price of $76.79 \%$ in the PIKJ. PIKJ will quickly respond to price increases in production centers even though the distance from the production center to the PIKJ is very far, the flow of price information that occurs is actually one-way from the PIKJ to the production center. The response to the high price increase is seen that the PIKJ is a price determinant and when 
viewed from the marketing actors involved in it turns out there are farmers in the production center which are dealers or traders in the PIKJ.

In this case to include the expectation factor about the future of something that is not easy, but the better the techniques and means of analysis, the easier it is to arrange these expectations, with the availability of information. In theory it is the development of economic models in the rational flow of expectations, this flow uses several propositions including: that people or economic units will make estimates (expectations), people do not use the information available to them efficiently, people do not make mistakes. errors systematically in expectations, and people will react rationally to policies carried out in their own personal interests.

Price formation in the Kramat teak main market occurs from wholesalers, dealers and centeng. The price information center in Kramat Jati gets prices from all traders in the Kramat Jati Teak main market, and submits it to 7 service agencies. Curly red chili prices from the Kramat teak main market under normal price conditions are forwarded to the Cikajang production center within 12 hours to the city and farmers, and when the price increase information is forwarded from the Kramat Main Market to the production center within 1 hour, and the information center prices at production centers get price information from farmers and dealers and are informed to the district agriculture office and the provincial agriculture office.

price formation in production centers is not seen to be formed from supply and demand. Prices in the wholesale market are prices determined by market participants in the wholesale market based on the amount of supply entering the wholesale market and price information between the wholesale markets. The information center in the Kramat Jati main market does not have production data from the production center, so when there is an increase in the price of the version of the Ministry of Agriculture is the import of chili ("special curly red chili there is no import"). Imports indicate production / supply is reduced without knowing the actual amount of production, in this case the speed of price information is faster than the production data that is informed per year so that prices in farmers still do not increase means farmers do not enjoy price increases, in this case it can be said that the market mechanism is not going well. Price solutions are more in favor of consumers, and imports are the best step for the government because chili is a strategic food commodity that is included in inflation.

the rational expectations model does not fully fit the conditions that occur in the curly red chili market. In the rational expectations model suggests doing nothing or not making policies and letting the market mechanism work. What happens when the price of curly red chili government sets a reference price because it is needed for economic stability when prices are not normal. The rational expectations model in this case shows several things that are not fulfilled, including perfect information, inadequate infrastructure, and low level of community education.

\section{CONCLUSION AND SUGGESTION}

The results of the analysis show that a price increase of 1 rupiah in Cikajang will increase the price in the PIKJ to 0.7679 rupiah, or an increase in price of $76.79 \%$, meaning an increase in prices in the center production will raise the price of $76.79 \%$ in the PIKJ. PIKJ will quickly respond to price increases in production centers even though the distance from the production center to the PIKJ is very far, the flow of price information that occurs is actually one-way from the PIKJ to the production center. The response to the high price increase is seen that the PIKJ is a price determinant and when viewed from the marketing 
actors involved in it turns out there are farmers in the production center which are dealers or traders in the PIKJ.

\section{REFERENCE}

Agustian, A., \& Anugrah, S. (2009). Analisis Perkembangan Harga Dan Rantai Pemasaran Komoditas Cabai Merah Di Provinsi Jawa Barat. Pusat Analisis Sosial Ekonomi Dan Kebijakan Pertanian, (3), 316-328.

Eni Istiyanti. (2010). Efisiensi pemasaran cabai merah keiting di kecamatan ngemplak kabupaten Sleman. Mapeta, XII(2), 116-124.

Rasidin, R., Yusriadi, Y., \& Rahman, R. (2018). ANALISIS PENDAPATAN DAN EFISIENSI PEMASARAN CABAI MERAH (Capsicum annuum L.) DI KECAMATAN WATANGPULU KABUPATEN SIDRAP. Jurnal Pendidikan Teknologi Pertanian, 4(2004), 84. https://doi.org/10.26858/jptp.v4i0.6916

Supriadi, H., \& Sejati, W. K. (2018). Perdagangan Antarpulau Komoditas Cabai di Indonesia: Dinamika Produksi dan Stabilitas Harga. Analisis Kebijakan Pertanian, 16(2), 111. https://doi.org/10.21082/akp.v16n2.2018.111-129

Tsurayya, S., \& Kartika, L. (2004). KELEMBAGAAN DAN STRATEGI PENINGKATAN DAYA SAING KOMODITAS CABAI Kabupaten garut. Jurnal Manajemen Dan Agribisnis, 12(1), 1-12. https://doi.org/10.17358/jma.12.1.1 